\title{
Worry in Children is Related to Perceived Parental Rearing and Attachment
}

Citation for published version (APA):

Muris, P. E. H. M., Meesters, C. M. G., Merckelbach, H. L. G. J., \& Hülsenbeck, P. (2000). Worry in Children is Related to Perceived Parental Rearing and Attachment. Behaviour Research and Therapy, 38, 487-497. https://doi.org/10.1016/S0005-7967(99)00072-8

Document status and date:

Published: 01/01/2000

DOI:

10.1016/S0005-7967(99)00072-8

Document Version:

Publisher's PDF, also known as Version of record

\section{Please check the document version of this publication:}

- A submitted manuscript is the version of the article upon submission and before peer-review. There can be important differences between the submitted version and the official published version of record.

People interested in the research are advised to contact the author for the final version of the publication, or visit the DOI to the publisher's website.

- The final author version and the galley proof are versions of the publication after peer review.

- The final published version features the final layout of the paper including the volume, issue and page numbers.

Link to publication

\footnotetext{
General rights rights.

- You may freely distribute the URL identifying the publication in the public portal. please follow below link for the End User Agreement:

www.umlib.nl/taverne-license

Take down policy

If you believe that this document breaches copyright please contact us at:

repository@maastrichtuniversity.nl

providing details and we will investigate your claim.
}

Copyright and moral rights for the publications made accessible in the public portal are retained by the authors and/or other copyright owners and it is a condition of accessing publications that users recognise and abide by the legal requirements associated with these

- Users may download and print one copy of any publication from the public portal for the purpose of private study or research.

- You may not further distribute the material or use it for any profit-making activity or commercial gain

If the publication is distributed under the terms of Article $25 \mathrm{fa}$ of the Dutch Copyright Act, indicated by the "Taverne" license above, 


\title{
Worry in children is related to perceived parental rearing and attachment
}

\author{
Peter Muris $^{\mathrm{a}, *}$, Cor Meesters $^{\mathrm{b}}$, Harald Merckelbach ${ }^{\mathrm{a}}$, Paulette Hülsenbeck ${ }^{\mathrm{b}}$ \\ ${ }^{a}$ Department of Psychology, Maastricht University, Netherlands \\ ${ }^{\mathrm{b}}$ Department of Experimental Abnormal Psychology, Maastricht University, P.O. Box 616, 6200 MD, Maastricht, \\ Netherlands
}

\begin{abstract}
In a sample of 159 primary school children, the relationship between perceived parental rearing behaviours and self-reported attachment style, on the one hand, and worry, on the other hand, was investigated. Children completed (a) the EMBU, a questionnaire measuring perceptions of parental rearing behaviours, (b) a single-item measure of attachment style, and (c) the Penn State Worry Questionnaire for Children (PSWQ-C), an index of severity of worrying. Results showed that parental rearing behaviours, in particular rejection and anxious rearing, were positively associated with worry. Thus, children who perceived their parents as more rejective and anxious reported higher levels of worry. Furthermore, self-reported attachment style appeared to be related to worry. More specifically, children who classified themselves as avoidantly or ambivalently attached displayed higher levels of worry than did children who classified themselves as securely attached. These findings are consistent with the notion that family environment factors such as parental rearing and attachment style contribute to the severity of anxiety symptoms in children. (C) 2000 Elsevier Science Ltd. All rights reserved.
\end{abstract}

Keywords: Parental rearing behaviours; Attachment style; Worry; Self-report; Children

\section{Introduction}

There is some evidence to suggest that family environment is involved in the development of

\footnotetext{
* Corresponding author.

E-mail address: p.muris@psychology.unimaas.nl (P. Muris).
}

0005-7967/00/\$ - see front matter (C) 2000 Elsevier Science Ltd. All rights reserved.

PII: S0005-7967(99)00072-8 
anxiety symptoms in children (e.g. Rapee, 1997). Basically, this evidence comes from two research lines. The first line is inspired by attachment theory and focuses on early parent-child interactions. The second line is based on a broader perspective and examines the connection between ongoing parental rearing behaviours (parental rearing styles) and anxiety.

Attachment theory proposes that children's level of anxiety is affected by the way in which they are attached to their caregivers (Bowlby, 1973). Research has, indeed, shown that early attachment relationships are predictors of fear and anxiety in later childhood. For example, in their longitudinal, prospective study, Warren, Huston, Egeland and Sroufe (1997) classified infants as either securely or insecurely attached. When children reached 17.5 years of age, current and past anxiety disorders were assessed by means of an interview schedule. Insecurely attached children more frequently suffered from anxiety disorders (e.g. overanxious disorder, separation anxiety disorder, and social phobia) than did control children. A recent study by Muris, Mayer and Meesters (1999) further examined the connection between attachment styles and anxiety disorders symptoms. Normal children were asked to complete a simplified version of Hazan and Shaver's (1987) single-item measure of attachment style and the Screen for Child Anxiety Related Emotional Disorders (SCARED; Birmaher et al., 1997; Muris, Merckelbach, Schmidt \& Mayer, 1999) which taps DSM-defined anxiety disorders symptoms. In agreement with Bowlby's (1973) position, insecurely (i.e. avoidantly and ambivalently) attached children exhibited elevated levels of anxiety disorders symptomatology compared to securely attached children.

While attachment researchers emphasize that disturbances in early parent-child interactions promote the development of high anxiety levels in children, others have stressed the importance of particular parental rearing styles. Support for this position comes from two sources. The first source relies on direct observation of current parent-child interactions. Following such an approach, Dadds and colleagues (Dadds, Barrett \& Rapee, 1996; see, for a review, Dadds \& Barrett, 1996) noted that parents of anxious children often encourage their children to rely on avoidant coping strategies. The second source consists of studies relying on questionnaires that intend to measure children's perceptions of parental rearing behaviours. For example, in two subsequent studies by Muris and colleagues (Muris \& Merckelbach, 1998; Grüner, Muris \& Merckelbach, 1999), normal school children completed a modified version of the EMBU for children (EMBU-C; Egna Minnen Betraffende Uppfostran-My memories of upbringing; Castro, Toro, Van der Ende \& Arrindell, 1993), a questionnaire assessing children's perceptions of parental rearing behaviours. Additionally, children completed a scale measuring anxiety disorders symptoms (e.g. the SCARED; cf. supra). The results of both studies revealed significant and positive relationships between anxious rearing behaviours, parental control, and rejection, on the one hand, and anxiety disorders symptomatology, in particular symptoms of generalized anxiety disorder and separation anxiety disorder, on the other hand.

Worry is an important feature of childhood anxiety (e.g. Perrin \& Last, 1997). It is defined as "a chain of thoughts and images, negatively affect-laden and relatively uncontrollable" (Borkovec, Robinson, Pruzinsky \& DePree, 1983, p. 9). In the latest edition of the Diagnostic and Statistical Manual of Mental Disorders (i.e. DSM-IV; American Psychiatric Association, 1994), worry is described as a core symptom of generalized anxiety disorder. Apart from this, worry plays a role in several other anxiety disorders (e.g. separation anxiety disorder and social 
phobia; see Weems, Silverman \& La Greca, 1999). Over the past few years, a number of studies have shown that worry is not only present in anxiety disordered children, but also frequently occurs in healthy children. For example, in their sample of primary school children $(N=193)$, Muris, Meesters, Merckelbach, Sermon and Zwakhalen (1998) found that almost $70 \%$ of them worried every now and then. Moreover, it appeared that about $5 \%$ of these children exhibited symptoms of worry in the pathological range and met the DSM criteria of generalized anxiety disorder.

The present study examined the connection between family environment factors and worry in a sample of primary school children. Two types of family environment factors were included. First of all, children's attachment style was assessed by means of a simplified version of Hazan and Shaver's (1987) single-item measure (cf. supra). This measure provides children with three descriptions concerning their feelings about relationships with other children. Children are instructed to choose the description that applies best to them. It is assumed that children's preference for a certain interactional pattern reflects their habitual attachment styles (see, for a discussion, Stein, Jacobs, Ferguson, Allen \& Fonagy, 1998). In this way, children's attachment style is classified as either 'secure', 'avoidant', or 'ambivalent'. The second family environment factor, parental rearing styles, was measured with a modified version of the EMBU-C (cf. supra). This scale taps four separate domains of ongoing parental rearing behaviours: emotional warmth, rejection, parental control, and anxious rearing. Worry was assessed by means of the Penn State Worry Questionnaire for Children (PSWQ-C; Chorpita, Tracey, Brown, Collica \& Barlow, 1997), a reliable and valid 14-item scale measuring severity of worrying in children.

To summarize, then, the current study explored the links between attachment style and parental rearing styles, on the one hand, and worry, on the other hand. More specifically, it was tested (a) whether children who classify themselves as insecurely (i.e. avoidantly or ambivalently) attached report a stronger tendency to worry compared to children who classify themselves as securely attached, and (b) whether rejective, controlling, and anxious rearing behaviours are accompanied by heightened levels of worry.

\section{Method}

\subsection{Children and procedure}

One hundred and fifty-nine children ( 82 boys and 77 girls) were recruited after parents and teachers had given informed consent. The children attended regular classes of primary schools 'De Nutsschool' en 'De Vink' in Voorschoten, The Netherlands. Mean age of the children was 10.82 ( $\mathrm{SD}=0.91$, range 9-13 years). Percentages of children with low, middle, and upper socioeconomic background were 30,65, and 5\%, respectively. Most children were Caucasian (95\%). Questionnaires were administered to the children during regular classes. The teacher and a research assistant were present in order to answer questions and provide clarification if necessary. 


\subsection{Questionnaires}

\subsubsection{Attachment styles}

Hazan and Shaver's (1987) prototypic descriptions of attachment patterns were used. Because the present study relied on a child sample, the descriptions were somewhat simplified: (1) 'I find it easy to become close friends with other children. I trust them and I am comfortable depending on them. I do not worry about being abandoned or about another child getting too close friends with me' (secure attachment), (2) 'I am uncomfortable to be close friends with other children. I find it difficult to trust them completely, difficult to depend on them. I get nervous when another child wants to become close friends with me. Friends often come more close to me that I want them to' (avoidant attachment), (3) 'I often find that other children do not want to get as close as I would like them to be. I am often worried that my best friend doesn't really like me and wants to end our friendship. I prefer to do everything together with my best friend. However, this desire sometimes scares other children away' (ambivalent attachment). Children were provided with these descriptions and instructed to choose the description that applied best to them.

\subsection{2. $E M B U-C$}

The modified version of the EMBU-C (Castro et al., 1993) consists of 40 items that can be allocated to four subscales each representing a domain of parental rearing: emotional warmth (10 items; e.g. 'Your parents show that they love you'), rejection (10 items; e.g. 'Your parents wish that you were like somebody else'), control (10 items; e.g. 'Your parents want you to reveal your secrets to them'), and anxious rearing (10 items; e.g. 'Your parents are scared when you do something on your own'). All items are answered on a 4-point Likert scale $(1=$ No, never, $2=$ Yes, but seldom, $3=$ Yes, often, $4=$ Yes, most of the time). For each EMBU-C item, children first assessed father's rearing behaviour and then mother's rearing behaviour.

\subsection{3. $P S W Q-C$}

This questionnaire consists of 14 items (e.g. 'I worry all the time', 'I am always worrying about something', and 'My worries really bother me'; Chorpita et al., 1997) that are scored on a 4-point scale: $0=$ never, $1=$ sometimes, $2=$ often, and $3=$ always. A total score is computed ranging between 0 and 42 , with higher scores reflecting a stronger tendency to worry.

\section{Results}

\subsection{General statistics}

Before discussing the main results of the present study, three remarks are in order. To begin with, questionnaires were found to be reliable in terms of internal consistency. As is shown in Table 1, Cronbach's alphas of various EMBU-C scales varied between 0.61 (control of mother) and 0.76 (rejection of mother). For the PSWQ-C, alpha was 0.79. Secondly, $t$-tests revealed significant gender differences only for the EMBU-C rejection scales: boys perceived their father and mother as more rejective than girls $[t(157)=3.03, P<0.005$ and $t(157)=2.57, P<0.05$, 
respectively; see Table 1]. Third and finally, there were no significant associations between age and any of the measures.

\subsection{Attachment style and worry}

The number of children who endorsed the secure, avoidant, or ambivalent attachment items was 130 (81.8\%; 74 boys, 56 girls), 8 (5.0\%; 3 boys, 5 girls), and 21 (13.2\%; 5 boys, 16 girls), respectively. A $\chi^{2}$ test revealed that boys and girls differed with regard to attachment styles, with girls classifying themselves more frequently as insecurely (in particular ambivalently) attached than boys $\left[\chi^{2}(1)=8.2, P<0.005\right]$.

Fig. 1 presents mean worry scores of children who classified themselves as either securely, avoidantly, or ambivalently attached. To examine the effects of attachment style on worry, a 2 (gender) $\times 3$ (attachment style) Analysis of Variance (ANOVA) was conducted. Results revealed a significant effect of attachment style $[F(2,153)=3.80, P<0.05]$. Post-hoc $t$-tests indicated that securely attached children displayed lower worry scores than avoidantly $(P<$ $0.05)$ and ambivalently attached $(P<0.005)$ children. No difference in worry scores was found between avoidantly and ambivalently attached children. Furthermore, the ANOVA yielded a significant interaction of gender and attachment style $[F(2,153)=3.96, P<0.05]$. As can be seen in Fig. 1, both avoidantly and ambivalently attached girls displayed higher worry scores than their securely attached counterparts. Conversely, only avoidantly attached boys exhibited

Table 1

General statistics (means, standard deviations, gender differences, and Cronbach's alphas) of PSWQ-C and EMBU$\mathrm{C}$, and the number (percentage) of children who classified themselves as either securely, avoidantly, or ambivalently attached

\begin{tabular}{lcccc}
\hline & Total $(N=159)$ & Boys $(n=82)$ & Girls $(n=77)$ & $\alpha$ \\
\hline PSWQ-C & $14.65(5.44)$ & $14.24(5.42)_{\mathrm{a}}$ & $15.09(5.48)_{\mathrm{a}}$ & 0.79 \\
EMBU-C Mother & & & & \\
Anxious Rearing & $21.58(4.41)$ & $22.48(4.23)_{\mathrm{a}}$ & $20.62(4.42)_{\mathrm{a}}$ & 0.75 \\
Control & $20.97(3.73)$ & $21.23(4.13)_{\mathrm{a}}$ & $20.69(3.24)_{\mathrm{a}}$ & 0.61 \\
Emotional Warmth & $31.16(4.14)$ & $30.76(4.51)_{\mathrm{a}}$ & $31.60(3.70)_{\mathrm{a}}$ & 0.74 \\
Rejection & $14.91(3.53)$ & $15.60(3.82)_{\mathrm{a}}$ & $14.18(3.05)_{\mathrm{b}}$ & 0.76 \\
EMBU-C Father & & & & \\
Anxious Rearing & $20.21(4.34)$ & $20.45(4.11)_{\mathrm{a}}$ & $19.95(4.59)_{\mathrm{a}}$ & 0.74 \\
Control & $19.15(3.78)$ & $19.20(4.01)_{\mathrm{a}}$ & $19.10(3.56)_{\mathrm{a}}$ & 0.66 \\
Emotional Warmth & $30.65(4.35)$ & $30.20(4.84)_{\mathrm{a}}$ & $31.14(3.72)_{\mathrm{a}}$ & 0.74 \\
Rejection & $14.48(3.34)$ & $15.24(3.77)_{\mathrm{a}}$ & $13.68(2.60)_{\mathrm{b}}$ & 0.75 \\
Attachment styles & & & & \\
Secure & $130^{*}(81.8)$ & $74^{*}(90.2)_{\mathrm{a}}$ & $56^{*}(72.7)_{\mathrm{b}}$ & $5^{*}(6.5)_{\mathrm{a}}$ \\
Avoidant & $8^{*}(5.0)$ & $3^{*}(3.7)_{\mathrm{a}}$ & $16^{*}(20.8)_{\mathrm{b}}$ & $*$ \\
Ambivalent & $21^{*}(13.2)$ & $5^{*}(6.1)_{\mathrm{a}}$ & \\
\hline
\end{tabular}

\footnotetext{
${ }^{\text {a }}$ PSWQ-C = Penn State Worry Questionnaire for Children; EMBU-C=Child version of the EMBU; means and numbers (percentages) in the same row that do not share the same subscripts differ at $P<0.05 .{ }^{*}$ Attachment styles were assessed by means of a 1-item measure. Therefore, Cronbach's alpha could not be computed.
} 


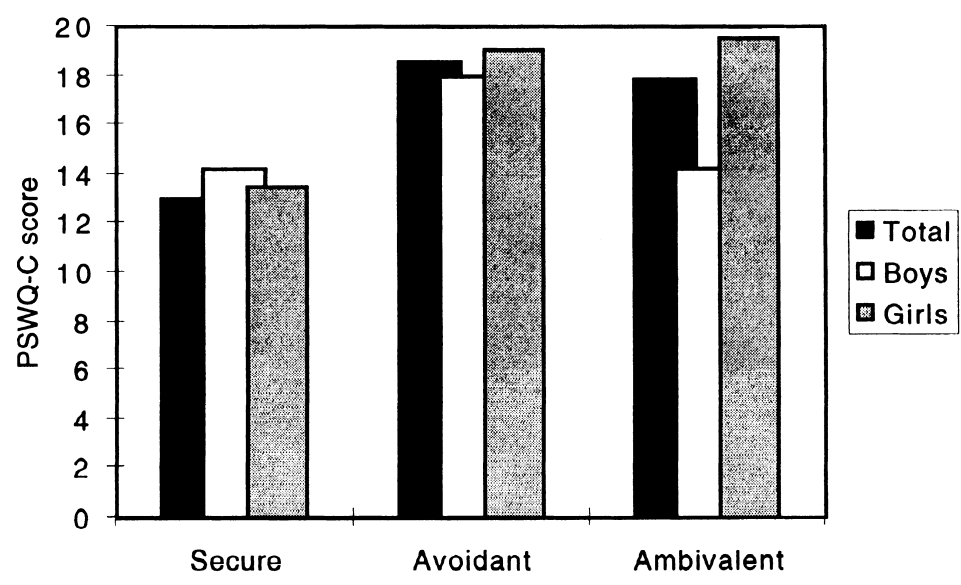

Note. PSWQ-C = Penn State Worry Questionnaire for Children

Fig. 1. Mean PSWQ-C scores of children who classified themselves as either securely, avoidantly, or ambivalently attached.

heightened worry scores, whereas ambivalently attached boys displayed similar low levels as securely attached children.

\subsection{Parental rearing behaviours and worry}

Pearson product-moment correlations were computed in order to examine the connection between perceived parental rearing behaviours and worry. As can be seen in Table 2, in both

Table 2

Pearson product-moment correlations between EMBU-C and PSWQ-C, for the total sample $(N=159)$ and for boys $(n=82)$ and girls $(n=77)$, separately

\begin{tabular}{lccc}
\hline & \multicolumn{2}{c}{ Correlation with PSWQ-C $^{\mathrm{a}}$} \\
\cline { 2 - 4 } & Total & Boys & \\
\hline EMBU-C Mother & & & 0.18 \\
Anxious Rearing & $0.27^{* * *}$ & $0.41^{* * *}$ & 0.18 \\
Control & $0.22^{* *}$ & $0.27^{*}$ & 0.14 \\
Emotional Warmth & -0.08 & $-0.26^{*}$ & $0.28^{*}$ \\
Rejection & $0.33^{* * *}$ & $0.41^{* * *}$ & 0.15 \\
EMBU-C Father & & & $0.24^{*}$ \\
Anxious Rearing & $0.19^{*}$ & 0.20 & 0.05 \\
Control & 0.13 & -0.09 & 0.03 \\
Emotional Warmth & -0.03 & $0.29^{* *}$ & $0.29^{* *}$ \\
Rejection & $0.26^{* *}$ & & \\
\hline
\end{tabular}

Notes $\mathrm{PSWQ}-\mathrm{C}=$ Penn State Worry Questionnaire for Children, EMBU-C $=$ Child version of the EMBU ${ }^{*} P<0.05$, ${ }^{* *} P<0.01,{ }^{* * *} P<0.001$. 
boys and girls, rejection attributed to father or mother was positively related to worry. Furthermore, in boys, positive relationships were found between perceived anxious rearing of father or mother and control of mother, on the one hand, and worry, on the other hand. Finally, a negative correlation was found between emotional warmth ascribed to mother and worry. Altogether, these data are in line with the view that higher levels of rejection, control, and anxious rearing and lower levels of emotional warmth are accompanied by higher levels of worry.

\subsection{Parental rearing behaviours, attachment status, and worry}

To explore the relationships between both family environment factors, a series of 2 (gender) $\times 3$ (attachment style) ANOVAs with EMBU-C scales of father and mother as the dependent variables was carried out. Results indicated that the three attachment style groups differed in terms of perceived anxious rearing and rejection of both the father and the mother. Post-hoc $t$ tests revealed that, with regard to anxious rearing, ambivalently attached children deviated significantly from securely attached children. More precisely, ambivalently attached children more often reported anxious rearing than securely attached children. Also, avoidantly attached and securely attached children differed significantly from each other in terms of perceived rejection. As can be seen in Table 3, avoidantly attached children more often reported parental rejection than securely attached children.

To examine the relative contribution of both family environment factors to children's levels of worry, a series of stepwise regression analyses was conducted with EMBU-C scales and attachment status (i.e., a dummy variable with secure attachment $=0$ and avoidant/ambivalent attachment $=1$ ) being predictors and PSWQ-C being the dependent variable. The results of these analyses are shown in Table 4. As can be seen, both insecure attachment and parental rearing behaviours, especially perceived rejection and anxious rearing, explained modest, but significant proportions of the variance of worry scores.

\section{Discussion}

The present study investigated the relationship between family environment factors and worry in a group of normal school children. The main results can be catalogued as follows. First of all, self-reported attachment style appeared to be related to worry. More specifically, children who classified themselves as avoidantly or ambivalently attached displayed higher worry levels than children who classified themselves as securely attached. Second, perceived parental rearing behaviours, in particular rejection and anxious rearing, were found to be positively associated with worry. That is, the more children, and especially boys, perceived their parents as rejective and anxious the higher their levels of worry.

The percentages of children who endorsed the secure, avoidant, and ambivalent attachment items came close to those found in our previous study (Muris et al., 1999). In both studies, only 1 out of 5 children reported to have an ambivalent or avoidant attachment style. Attachment researchers who employed Ainthworth, Blehar, Waters and Wall's (1978) strange situation procedure to measure attachment types in infancy found considerably higher 
Table 3

Mean EMBU-C scores for children who classified themselves as either securely, avoidantly, or ambivalently attached

\begin{tabular}{|c|c|c|c|c|c|c|c|c|c|c|c|c|c|}
\hline & \multicolumn{3}{|c|}{ Secure } & \multicolumn{3}{|c|}{ Avoidant } & \multicolumn{3}{|c|}{ Ambivalent } & \multicolumn{3}{|c|}{ ANOVAs (F values) } & \multirow[b]{2}{*}{ Post-hoc tests ${ }^{\mathrm{b}}$} \\
\hline & $\operatorname{Total}(N=130)$ & Boys $(n=74)$ & $\operatorname{Girls}(n=56)$ & $\operatorname{Total}(N=8)$ & Boys $(n=3)$ & $\operatorname{Girls}(n=5)$ & $\operatorname{Total}(N=21)$ & Boys $(n=5)$ & Girls $(n=16)$ & Group & Gender & Interaction & \\
\hline \multicolumn{14}{|c|}{ EMBU-C ${ }^{\mathrm{a}}$ Mother } \\
\hline Anxious Rearing & $21.21(4.28)$ & $22.34(4.32)$ & $19.71(3.75)$ & $23.63(3.34)$ & $24.33(3.21)$ & $23.20(3.70)$ & $23.10(5.15)$ & $23.40(3.36)$ & $23.00(5.68)$ & $3.1^{*}$ & ns & ns & Secure $<$ Ambivalent \\
\hline Control & $20.75(3.78)$ & $21.23(4.20)$ & $20.11(3.07)$ & $22.00(2.67)$ & $21.67(2.52)$ & $22.20(3.03)$ & $21.95(3.64)$ & $21.00(4.64)$ & $22.25(3.40)$ & ns & ns & ns & \\
\hline Emotional Warmth & $30.90(4.28)$ & 30.51 (4.59) & $31.41(3.82)$ & 32.88 (3.09) & $33.67(2.31)$ & $32.40(3.65)$ & $32.14(3.40)$ & $32.60(3.65)$ & 32.00 (3.43) & $\mathrm{ns}$ & ns & ns & \\
\hline $\begin{array}{l}\text { Rejection } \\
E M B U-C \text { Father }\end{array}$ & $14.69(3.51)$ & $15.43(3.84)$ & $13.71(2.75)$ & $17.50(4.66)$ & $19.33(3.06)$ & $16.40(5.41)$ & $15.29(2.87)$ & $15.80(3.11)$ & $15.13(2.87)$ & $3.6^{*}$ & $3.1^{*}$ & ns & Secure $<$ Avoidant \\
\hline Anxious Rearing & $19.72(4.07)$ & $20.22(4.18)$ & $19.05(3.85)$ & $22.00(4.21)$ & $22.00(1.73)$ & $22.00(5.43)$ & $22.57(5.22)$ & $23.00(3.32)$ & $22.44(5.77)$ & $4.4^{*}$ & ns & ns & Secure $<$ Ambivalent \\
\hline Control & $18.96(3.70)$ & $19.22(4.04)$ & $18.63(3.19)$ & $19.00(3.55)$ & $18.33(4.51)$ & $19.40(3.36)$ & 20.38 (4.32) & $19.40(4.04)$ & $20.69(4.48)$ & ns & ns & ns & \\
\hline Emotional Warmth & $30.52(4.55)$ & $30.01(4.94)$ & $31.20(3.91)$ & $31.25(3.20)$ & $31.67(5.13)$ & $31.00(2.12)$ & $31.24(3.42)$ & $32.00(2.92)$ & $31.00(3.61)$ & ns & ns & ns & \\
\hline Rejection & $14.23(3.07)$ & $14.95(3.37)$ & $13.29(2.34)$ & $17.25(6.76)$ & $22.00(8.72)$ & $14.40(3.85)$ & $15.00(2.76)$ & $15.60(2.70)$ & $14.81(2.83)$ & $6.6^{* *}$ & $12.5^{* *}$ & $3.5^{*}$ & Secure $<$ Avoidant \\
\hline
\end{tabular}

${ }^{\mathrm{a}} \mathrm{EMBU}-\mathrm{C}=$ Child version of the EMBU.

${ }^{\mathrm{b}}$ Evaluating the differences between securely, avoidantly, and ambivalently attached children. ${ }^{*} P<0.05,{ }^{* *} P<0.005$, ns $=$ nonsignificant. 
percentages for ambivalent and avoidant attachment (15 and 20\%, respectively; see, for example, Campos, Barrett, Lamb, Goldsmith \& Stenberg, 1983). Similar percentages have been reported for adult studies that used Hazan and Shaver's (1987) single-item measure of attachment. Thus, it appears that insecure attachment types are less common in children aged 9-12 years than in either infants or adults. Two possible explanations for this finding suggest themselves. To begin with, it may well be the case that insecure attachment patterns are less prominent in middle childhood because in this developmental phase concerns about friendship and relationships to other children play a minor role. However, early attachment patterns would be reintensified as soon as the child is confronted with potentially stressful situations (e.g. the child's entry in a new school; see Main, Kaplan \& Cassidy, 1985; Bretherton, 1985). The second explanation has to do with differences in measurement tools. More specifically, it is possible that with the single-item measure of attachment used in the current study, children aged 9-12 years have a tendency to endorse the positive toned, secure attachment item rather than the more negative descriptions of avoidant and ambivalent attachment. Thus, reliance on a single-item instrument to assess children's attachment style may lead to underreporting of insecure attachment types.

The current study found significant associations between perceived parental rearing behaviours and attachment style. More specifically, anxious rearing appeared to be related to ambivalent attachment, whereas rejection was connected to avoidant attachment. This might imply that anxious rearing results in an ambivalent attachment style, whereas rejection leads to an avoidant attachment style. However, acknowledging the correlational approach of the current study, it is also possible that anxious and rejective rearing behaviours of parents are elicited by ambivalently or avoidantly attached children, respectively.

The results of the present study indicate that both attachment style and perceived parental rearing are linked to severity of children's worry. This is well in line with previous studies showing that insecurely attached children and adults exhibit higher levels of anxiety and depression compared to their securely attached counterparts (e.g. Muris et al., 1999; Priel \& Shamai, 1995). Kobak and Sceery (1988) argued that the higher levels of psychopathology in insecurely attached individuals may originate from their poor ability to control affect. For example, insecurely attached individuals expect less social support when confronted with stressful situations and this would make them more vulnerable to develop psychopathology

Table 4

Main results of forward regression analyses with EMBU-C scales and attachment status being predictors and PSWQ-C being the dependent variable (while controlling for gender)

\begin{tabular}{|c|c|c|c|c|}
\hline Dependent & Predictors & Partial $r$ & $P$ & $R^{2}$ change \\
\hline \multicolumn{5}{|c|}{ EMBU-C scales-Mother-and Insecure Attachment } \\
\hline \multirow[t]{3}{*}{ PSWQ-C } & 1. Rejection & 0.35 & $<0.001$ & 12.3 \\
\hline & 2. Insecure Attachment & 0.24 & $<0.005$ & 5.0 \\
\hline & 3. Anxious Rearing & 0.18 & $<0.05$ & 2.7 \\
\hline \multicolumn{5}{|c|}{ EMBU-C scales - Father-and Insecure Attachment } \\
\hline \multirow[t]{2}{*}{ PSWQ-C } & 1. Insecure Attachment & 0.28 & $<0.001$ & 8.1 \\
\hline & 2. Rejection & 0.24 & $<0.005$ & 5.0 \\
\hline
\end{tabular}


(Kobak \& Sceery, 1988). While this line of reasoning seems plausible, one could counter that the relationship between attachment style and a psychopathological symptom such as worry is tautological in nature. While it should be noted that none of the items of the worry scale used in the present study (i.e. the PSWQ-C) refers to worry in social contexts, it remains possible that worry contributes to a preference for negative attachment descriptions rather than vice versa. Relatedly, the present data add further weight to earlier studies that reported a connection between parental rearing behaviours and anxiety symptoms (Muris \& Merckelbach, 1998; Grüner et al., 1999). A recurrent finding in all these studies is that higher levels of rejection, anxious rearing, and to a lesser extent, parental control are accompanied by higher levels of anxiety (see for a review, Rapee, 1997). Again, it is tempting to interpret parental rearing styles as antecedents and anxiety levels as consequences. However, it cannot be ruled out that higher levels of worry underly less favourable reports of parental rearing. Thus, it should be stressed that like previous studies, the current study employed a correlational approach that cannot resolve the causality issue. In addition, regression analyses revealed that attachment style and parental rearing behaviours only accounted for a relatively small percentage of the variance of children's worry scores (i.e. between 13.1 and 20\%). This underlines the idea that other factors such as specific life events and genetically transmitted temperament are involved in the development of childhood anxiety symptoms such as worry (e.g. Bernstein, Borchardt \& Perwien, 1996; Craske, 1997; Spence \& Dadds, 1996).

To sum up, then, the current study indicates that perceived parental rearing and attachment are linked to worry. This finding is consistent with those theories that stress the role of rearing and attachment as developmental factors in the etiology of anxiety symptoms such as worry (e.g. Muris \& Merckelbach, 1999). Yet, it is also conceivable that children who frequently engage in worrying tend to describe their attachment and their parents' rearing style in negative terms. This is a distinct possibility that warrants further study.

\section{Acknowledgements}

Teachers, staff, and children of primary schools 'De Nutsschool' and 'De Vink' in Voorschoten, The Netherlands, are thanked for their participation in the present study.

\section{References}

American Psychiatric Association (1994). Diagnostic and statistical manual of mental disorders (4th ed.). Washington, DC: American Psychiatric Association.

Ainsworth, M. D. S., Blehar, M. C., Waters, E., \& Wall, S. (1978). Patterns of attachment: a psychological study of the strange situation. Hillsdale, NJ: Erlbaum.

Bernstein, G. A., Borchardt, C. M., \& Perwien, A. R. (1996). Anxiety disorders in children and adolescents: a review of the past 10 years. Journal of the American Academy of Child and Adolescent Psychiatry, 35, 1110-1119.

Birmaher, B., Khetarpal, S., Brent, D., Cully, M., Balach, L., Kaufman, J., \& McKenzie, Neer S. (1997). The Screen for Child Anxiety Related Emotional Disorders (SCARED): scale construction and psychometric characteristics. Journal of the American Academy of Child and Adolescent Psychiatry, 36, 545-553.

Borkovec, T. D., Robinson, E., Pruzinsky, T., \& De Pree, J. A. (1983). Preliminary exploration of worry: some characteristics and processes. Behaviour Research and Therapy, 21, 9-16. 
Bowlby, J. (1973). Attachment and loss: Volume 2. Separation: anxiety and anger. New York: Basic Books.

Bretherton, I. (1985). Attachment theory: retrospect and prospect. In I. Bretherton, \& E. Waters, Growing points of attachment theory and research. Chicago: University of Chicago Press.

Campos, J. J., Barrett, K. C., Lamb, M. E., Goldsmith, H. H., \& Stenberg, C. (1983). Socioemotional development. In M. M. Haidt, \& J. J. Campos, Handbook of child psychology. Volume 2. Infancy and psychobiology. New York: Wiley.

Castro, J., Toro, J., Van der Ende, J., \& Arrindell, W. A. (1993). Exploring the feasibility of assessing perceived parental rearing styles in Spanish children with the EMBU. International Journal of Social Psychiatry, 39, 47-57.

Chorpita, B. F., Tracey, S. A., Brown, T. A., Collica, T. J., \& Barlow, D. H. (1997). Assessment of worry in children and adolescents: an adaptation of the Penn State Worry Questionnaire. Behaviour Research and Therapy, $35,569-581$.

Craske, M. G. (1997). Fear and anxiety in children and adolescents. Bulletin of the Menninger Clinic, 61, A4-A36.

Dadds, M. R., \& Barrett, P. M. (1996). Family processes in child and adolescent anxiety and depression. Behaviour Change, 13, 231-239.

Dadds, M. R., Barrett, P. M., \& Rapee, R. M. (1996). Family process and child anxiety and aggression: an observational analysis. Journal of Abnormal Child Psychology, 24, 715-734.

Grüner K., Muris P., Merckelbach H. (1999). The relationship between anxious rearing behaviours and anxiety disorders symptomatology in normal children. Journal of Behavior Therapy and Experimental Psychiatry (in press).

Hazan, C., \& Shaver, P. (1987). Romantic love conceptualized as an attachment process. Journal of Personality and Social Psychology, 52, 511-524.

Kobak, R. R., \& Sceery, A. (1988). Attachment in late adolescence: working models, affect regulation and representations of self and others. Child Development, 59, 135-146.

Main, M., Kaplan, N., \& Cassidy, J. (1985). Security in infancy, childhood, and adulthood: a move to the level of representation. In I. Bretherton, \& E. Waters, Growing points of attachment theory and research. Chicago: University of Chicago Press.

Muris, P., \& Merckelbach, H. (1998). Perceived parental rearing behaviour and anxiety disorders symptoms in normal children. Personality and Individual Differences, 25, 1199-1206.

Muris, P., \& Merckelbach, H. (1999). The etiology of childhood specific phobia: a multifactorial model. In M. W. Vasey, \& M. R. Dadds, The developmental psychopathology of anxiety. New York: Oxford University Press (in press).

Muris P., Mayer B., Meesters C. 1999 Attachment style, anxiety, and depression in children (submitted for publication).

Muris, P., Merckelbach, H., Schmidt, H., \& Mayer, B. (1999). The revised version of the Screen for Child Anxiety Related Emotional Disorders (SCARED-R): factor structure in normal children. Personality and Individual Differences, 26, 99-112.

Muris, P., Meesters, C., Merckelbach, H., Sermon, A., \& Zwakhalen, S. (1998). Worry in normal children. Journal of the American Academy of Child and Adolescent Psychiatry, 37, 703-710.

Perrin, S., \& Last, C. G. (1997). Worrisome thoughts in children referred for anxiety disorder. Journal of Clinical Child Psychology, 26, 181-189.

Priel, B., \& Shamai, D. (1995). Attachment style and perceived social support: effects of affect regulation. Personality and Individual Differences, 19, 235-241.

Rapee, R. M. (1997). Potential role of childrearing practices in the development of anxiety and depression. Clinical Psychology Review, 17, 47-67.

Spence, S. H., \& Dadds, M. R. (1996). Preventing childhood anxiety disorders. Behaviour Change, 13, $241-249$.

Stein, H., Jacobs, N. J., Ferguson, K. S., Allen, J. G., \& Fonagy, P. (1998). What do adult attachment scales measure? Bulletin of the Menninger Clinic, 62, 33-82.

Warren, S. L., Huston, L., Egeland, B., \& Sroufe, L. A. (1997). Child and adolescent anxiety disorders and early attachment. Journal of the American Academy of Child and Adolescent Psychiatry, 36, 637-644.

Weems, C. F., Silverman, W. K., Greca La, A. M. (1999). What do youth referred for anxiety problems worry about? Worry and its relation to anxiety and anxiety disorders in children and adolescents. Journal of Clinical Child Psychology (in press). 